\title{
Investigation of Tourism Interaction with Forest Fire Risk Areas in Cirali Region
}

\author{
Betül TÜLEK ${ }^{*}$, Arzu ALTUNTAŞ² \\ ${ }^{1}$ Çankırı Karatekin University, Faculty of Forestry, Department of Landscape Architecture, ÇANKIRI \\ ${ }^{2}$ Siirt University, Faculty of Agriculture, Department of Landscape Architecture, SİIRT
}

\begin{abstract}
Forest fires appear as a real destruction with human activities or natural forces. Despite the impossibilities to control the nature, it's possible to map fire risk areas and reduce the number of fires and prevent the damages. GIS can be used effectively to create a forest fire risk map with the capacity to evaluate the factors that cause fire. Cirali region, which is under constant fire threat were chosen for this research. Cirali region is located in Antalya province, southwest of Turkey as an agricultural village and a tourism area. As a result of the fire risk analysis, it has been determined that is concentrated around the residentials with high fire risk and the roads connecting the residentials. The interaction between Cirali region tourism and forest fire risk is analysed with the DPSIR model that shows the fire risk factors affecting the tourism in the region directly or indirectly.
\end{abstract}

Anahtar Kelimeler: Forest fire risks, tourism, GIS, DPSIR, Cirali region.

\section{Çıralı Bölgesindeki Orman Yangını Risk Alanları ile Turizm Etkileşiminin İncelenmesi}

Öz

Orman yangınları insan faaliyetleri veya doğal güçlerle gerçek bir yıkım olarak ortaya çıkar. Doğayı kontrol etmenin imkansızlıklarına rağmen, yangın riski alanlarını haritalamak ve yangın sayısını azaltmak ve hasarları önlemek mümkündür. CBS, yangına neden olan faktörleri değerlendirme kapasitesine sahip bir orman yangını risk haritası oluşturmak için etkin bir araç olarak kullanılabilir. Bu araştırma kapsamında Çıralı Bölgesi araştırma alanı olarak seçilmiştir. Çıralı Bölgesi Türkiye'nin güneybatısında, Antalya il sınırlarında, bir tarım köyü ve turizm alanı olarak yer almaktadır. Yangın riski analizi sonucunda, yangın riski yüksek olan alanların konutlar ile konutları birbirine bağlayan yollar çevresinde yoğunlaştığı tespit edilmiştir. Çıralı Bölgesi turizmi ile orman yangını riski arasındaki etkileşim, bölgedeki turizmi doğrudan veya dolaylı etkileyen yangın riski faktörlerini gösteren DPSIR modeli ile analiz edilmiştir.

Keywords: Yangın risk analizi, turizm, CBS, DPSIR, Çıralı bölgesi.

\footnotetext{
*Sorumlu Yazar (Corresponding Author):

Betül TÜLEK (Asst. Prof. Dr.); Çankırı Karatekin University, Faculty of Forestry,

Department of Landscape Architecture, 18200, Çankır1-Turkey. Tel: +90 (376) 218

9500, Fax: +90 (376) 213 6983, E-mail: betultulek@ karatekin.edu.tr

Received (Geliş) : 06.07.2020

Accepted (Kabul) : 23.12.2020

ORCID: 0000-0002-6584-041X 


\section{Introduction}

Many earthquakes, tsunamis, floods, forest fires, hurricanes, drought and heat waves called "natural disaster" have occurred and continue to come throughout world history. These natural disasters can occur spontaneously in the cycle of nature, as well as directly or indirectly due to human impact. Forest fires are undoubtedly one of the most common disasters due to anthropogenic factors.

Forest fires can occur due to various reasons and their distribution varies from country to country by region. The first and direct effect of fires is seen as destruction of vegetation and wildlife, degradation of soil structure, air pollution. Forest fires seen near residential areas can also threaten human health due to air pollution and cause the settlement areas to be destroyed. In addition, forest fires indirectly affect various sectors over time. One of these sectors is tourism.

Tourism is an action carried out in order to meet socio-cultural and psychological needs such as traveling, having fun, resting, learning, etc., and is a sector that contributes to the economies of countries by this action. Turkey is one of the countries that tourism activities are done so intensively in almost its every region with its geographical position. In addition to the cultural values of our country, natural areas / assets such as forests are also a major factor in the development of the tourism sector. Destruction of our natural areas / assets poses an important risk for the tourism sector as well as for many other sectors.

In this study, fire risk areas of forests located in Cirali region of Antalya, one of the most important tourism centers of our country, were determined with GIS and the interaction of fire risk with tourism has been demonstrated with DPSIR analysis based on Erten et al., 2005; Joaquim et al., 2007; Karabulut et al., 2013; Bingöl, 2017; Romagosa et al., 2014. The reasons for choosing the Cirali region as a research area, the tourism and recreation services are intensely in progress today, the location of the area, the existence of rare and endemic species, its natural, historical and cultural characteristics, the density of local settlements and agriculture in places can be shown. This study is important in terms of evaluating the fire sensitivity and tourism relations in the region together and producing the first data in this sense in the Landscape Architecture professional discipline of Cirali region.

\section{Material and method}

\subsection{Research area and general features}

Cirali region located in Kemer district of Antalya, is located within the borders of Olympos Beydaglari National Park. It is one of the most touristic regions of the Mediterranean Region. Through Ulupinar stream and canyon, Lycian road, Olympos, Yanartas and cedar forests, highlands, 1st and 2nd degree natural and historical protected areas, Cirali region has been protected from large-scale tourism and construction according to many regions around it, but it is still at risk. Cirali region (Figure 1) became a rural settlement in 1950s. Cirali economy is based on local tourism and agriculture. Cirali, located on the south-western coast of Antalya and having a $3.2 \mathrm{~km}$. long beach with its width varies between 50 to 100 meters, is very important habitat for Loggerhead Sea Turtle (Caretta caretta) (Tulek and Atik, 2017).

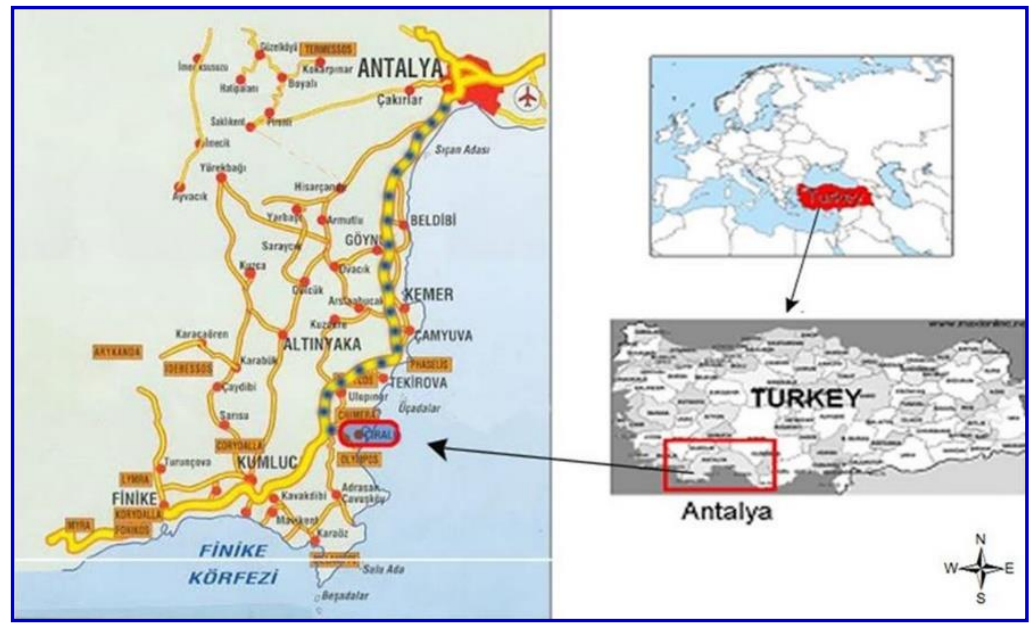

Figure 1. Location of research area. 
Kemer district of Antalya province, developed after 1980 has become one of Turkey's most important tourism centers. There are natural, historical and cultural areas such as Phaselis Ancient City, Cirali-Yanartas, Kadrama / Gedelma Castle, Idyros Ancient City and Calis Hill, Seljuq Hunting Lodge, Tahtali Mountain, Ayisigi Bay and Yoruk Park, Kesmebogazi Canyon, Molla Hole Cave, Ulupinar, Highlands, Goynuk Canyon, the Valley in Kuzdere. There are many different activities such as trekking, jeep safari, horse safari, enduro, mountain bike, caving, rock climbing, paragliding and nature photography. The Paris 2 shipwreck, which was sunk during the First World War and shown as one of the 100 dive sites in the world, was an important attraction for divers and underwater photographers after it was discovered in 1995 in Kemer (Kemer Municipality, 2019).

Tourism is one of the most important livelihoods in Kemer / Cirali region. Tourism structures in the region have increased since the 1980s and most of the touristic facilities are in the form of hostels. Cirali Region Ulupinar District Headman Habib Altınkaya stated that 100 percent occupancy rates are reached during the tourism seasons in Cirali region, which has a bed capacity of 16000 . Tourism structures are concentrated in the coastal part of the south-north connection. Daily facilities located on the coastal area are mainly gazebos and woods and meet the daily needs of Antalya. Most of the operating tourism facilities serve as family businesses. The vast majority of the local people who has got a hostel are also engaged in agriculture (Yamaner, 2008). Cirali natural landscapes are one of the most important factors in increasing the tourism attraction of this place.

Cirali coastal area can be considered as beaches and dunes. It consists of a low pebbly low beach zone lying close to horizontal and a sandy high beach zone that gradually rises in the land direction. The beach zone, which is relatively narrow on the Olympos side, is expanding towards Karaburun. In the part of the coastal cord, where the beach slope ends, starting with a marked slope fracture, the area extending near horizontal in the direction of the lands are dunes. Coastal dunes contain many rare plant and animal species (Yamaner, 2008).

Cirali Coastal Plain is an old lagoon floor filled with alluvions as a result of covering the front of the old Cirali Bay with a sandbar. There is a natural grove here. While a large part of Cirali Plain had the appearance of a marsh until 1987, agricultural production was started by making the drying channel made in the same year (Yamaner, 2008).

Ulupinar Stream is born from the 900 meter high slopes in the northwest of Ulupinar Village. Plane trees constitute the dominant vegetation of the valley floor of Ulupinar Stream. Although the dominant vegetation is red pine on the slopes of the valley, there are almost all types of maquis flora (Yamaner, 2008).

Yanartaş is one of the most touristy areas of Cirali. Yanartas is the name given by the local people to the natural gas that comes out of three different points in the serpentines on the southern slope of the Yanar Stream Valley. Here, there are continuous gas outlets on four different levels on an inclined surface of 80 meters (Yamaner, 2008).

In the mountainous hilly areas around Cirali, there are many paths with interesting views, flora and culture values, all of which have been used since ancient times. The most important of these are Ulupinar Valley Road, Ulupınar Connected Yanartas Trail, Olympos Road Trips, Coast Path Between Ulupinar Stream Mouth and Ak Creek Mouth and etc. In these paths, wild and grafted olives, wild pear, myrtle, pristine oak, turpentine tree, bay tree, locust, china tree, euphorbia, rhamnus, affodill grow up. There is a maki community consisting of a kind of ivy, which is called "sincan" by the local people. Under this cover is an extraordinarily rich cover formed by bulbous / flowering plants called crocuses, orchids and pork lumps. The vegetation exhibits a landscape where all shades of green and other colors blend, especially in autumn. The ancient city of Olympos, which is one of the most remarkable features of Cirali in terms of touristic activities, forms a whole with natural landscape, since most of the ruins are covered with laurel and blackberry bushes (Yamaner, 2008).

\subsection{Method}

Forest fires are closely related to the impact of features such as the geography, climate and vegetation in the Mediterranean Region (Sharples et al., 2009). Exposure of the region to large population mobility over time, in the forests and edges of the settlements establishment of forest fires has always remained a risk factor (Başaran et al., 2004). Accordingly, the following questions were sought in this study about the Cirali region:

1. Is tourism active in the region?

2. Has any fire risk been encountered in the region until today? If so, how were the results?

3. What is the probability of encountering a possible fire risk and how is this related to tourism and landscape characteristics of the region?

In this study, 2 different steps have been applied. In first step, different factors affecting forest fires such as vegetation, slope, aspect, distance to roads and residentials in the region were evaluated in the GIS. The evaluation was carried out in 3 different ways. All parameters are assigned risk factors according to their potential to create a 
fire risk. The most favorable condition for fire is expressed as "5" (Very risky) and the least favorable or unemployed condition as "1" (No Risk) (Table 1). Risk factor assigned data were evaluated with reference to equation 1 used in studies conducted by Erten et al. (2005) and Joaquim et al. (2007).

$$
\mathrm{RS}=7 * \mathrm{FT}+5 *(\mathrm{~S}+\mathrm{A})+3 *(\mathrm{Dr}+\mathrm{DR})
$$

$*$ RS = Fire Risk Level, FT= Potential Burning of Vegetation, $\mathrm{S}=$ Slope Conditions, A= Aspect Conditions, Dr= Distance to the road, DR= Distance to the Residential (Erten et al., 2005)

Table 1. Parameters and factors (Erten et al., 2005; Joaquim et al., 2007).

\begin{tabular}{|c|c|c|c|c|}
\hline Parameter & Weight & Class & Factor & Risk Classes \\
\hline \multirow{5}{*}{ Vegetation } & \multirow[t]{5}{*}{7} & Very Dry & 5 & Very Risky \\
\hline & & Dry & 4 & Risky \\
\hline & & Middle Moisture & 3 & Middle Risky \\
\hline & & Moisture & 2 & Little Risky \\
\hline & & Very Moisture & 1 & No Risk \\
\hline \multirow[t]{5}{*}{ Slope (\%) } & \multirow[t]{5}{*}{5} & $>30$ & 5 & Very Risky \\
\hline & & $20-30$ & 4 & Risky \\
\hline & & $10-20$ & 3 & Middle Risky \\
\hline & & $5-10$ & 2 & Little Risky \\
\hline & & $0-5$ & 1 & No Risk \\
\hline \multirow[t]{5}{*}{ Aspect } & \multirow[t]{5}{*}{5} & South & 5 & Very Risky \\
\hline & & West & 4 & Risky \\
\hline & & East & 3 & Middle Risky \\
\hline & & North & 2 & Little Risky \\
\hline & & Flat & 1 & No Risk \\
\hline \multirow[t]{5}{*}{ Distance to the road (m) } & \multirow[t]{5}{*}{3} & $0-100$ & 5 & Very Risky \\
\hline & & $100-200$ & 4 & Risky \\
\hline & & $200-300$ & 3 & Middle Risky \\
\hline & & $300-400$ & 2 & Little Risky \\
\hline & & $>400$ & 1 & No Risk \\
\hline \multirow[t]{5}{*}{ Distance to the Residential (m) } & \multirow[t]{5}{*}{3} & $0-500$ & 5 & Very Risky \\
\hline & & $500-1000$ & 4 & Risky \\
\hline & & $1000-1500$ & 3 & Middle Risky \\
\hline & & $1500-2000$ & 2 & Little Risky \\
\hline & & $>2000$ & 1 & No Risk \\
\hline
\end{tabular}

In second step landscape tourism factors are evaluated related to fire risk factors with DPSIR analysis. Environmental indicators are the main tools used to evaluate the pressure on the environment, the change caused by this pressure and the success of the environmental protection policies implemented. Because environmental indicators are the keys that turn a complex process or event into a more understandable form. Thus, they are an important source of information for policy makers and decision makers. The main problem here is the determination of the indicators that can "evaluate the entire ecological system in the most accurate and simplest way" (Anonymus, 2020).

Environmental indicators used since the 1980s have been developed with different approaches and models. One of these models is the DPSIR model developed by EEA (European Environment Agency). This model has five elements: D (Driving force), P (Pressure), S (State), I (Impact), R (Response). The Driving Forces are the changes in the social, economic and institutional system that directly and indirectly trigger pressures on the environmental situation (such as industry, agriculture, tourism, laws). Pressures are anthropogenic factors that cause environmental change (such as the use of natural resources in human activities, emissions). The Situation can express a natural system alone or a natural and socioeconomic system (Such as qualitative and quantitative characteristics of ecosystems, quantity and quality of resources, living conditions for humans). Impacts are changes in environmental functions that affect the social, economic and environmental dimensions resulting from changes in the state of the system. Responses are policy actions that are triggered directly or indirectly by the perception of effects and try to prevent, eliminate, compensate or reduce their consequences (Anonymus, 2020).

The DPSIR framework is widely used to analyze the links between different processes and the environment. Figure 2 shows the effects analysis of tourism on environmental assets and quality of life with the DPSIR model. 


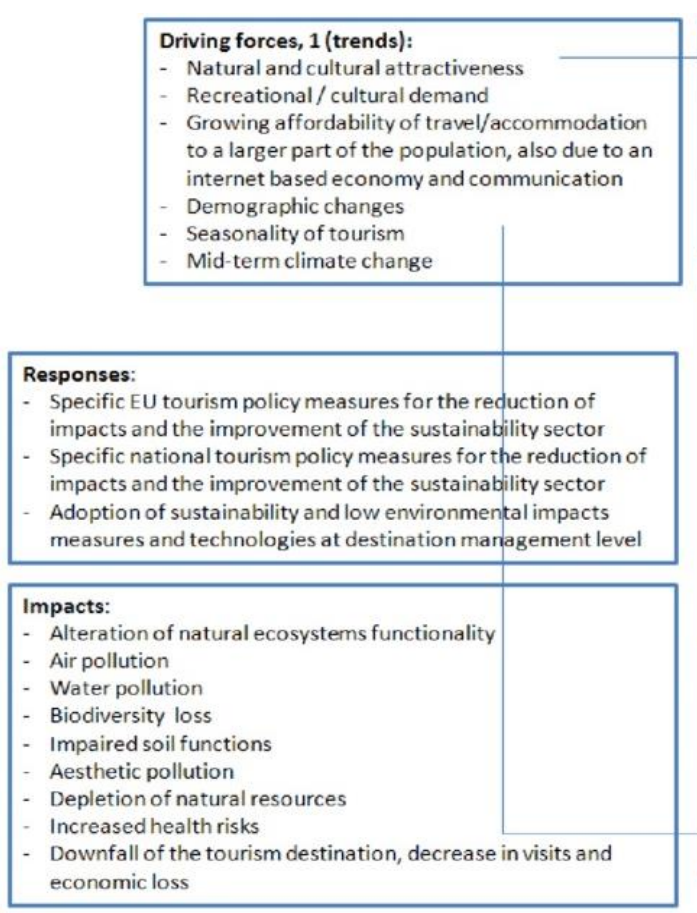

\begin{tabular}{|l|}
\hline Driving forces, 2 (actions): \\
\hline - Transport modes and infrastructure \\
- Food supply \\
- Energy supply \\
- Water supply \\
- Accommodation structures \\
- Access to sensitive natural areas / \\
ecosystems \\
\begin{tabular}{|l|}
\hline Pressures: \\
- Land take (tourism infrastructures) \\
- Air emissions \\
- Noise production (by different means of \\
transport and human activities) \\
- Natural resources use \\
- Solid waste production \\
- Waste water generation \\
- Water consumption \\
- Proximity to sensitive natural areas and \\
interferences with ecosystems \\
functionality \\
\hline State: \\
- Natural habitats fragmentation \\
- Landscape changes \\
- Changes in soil characteristics \\
- Air quality reduction \\
- Drinking water shortage \\
- Reduction of drinking water quality \\
\hline - Decreasing quality of bathing water \\
\hline
\end{tabular}
\end{tabular}

Figure 2. Location of research area DPSIR-Impacts-of-tourism-on-the-environmental-assets-and-quality-of-life (Romagosa et al., 2014).

\section{Bulgular ve Tartışma}

\subsection{Evaluation of risk factors}

\subsubsection{Climate and vegetation}

The region is under the effect of hot and dry summers and mild and rainy winters of Mediterranean climate. Average temperature in Kumluca is around $18.5{ }^{\circ} \mathrm{C}$, the highest temperature is recorded as $27.7^{\circ} \mathrm{C}$ in July and lowest temperature is recorded as $10.4{ }^{\circ} \mathrm{C}$ in January. Mediterranean vegetation forms the vegetation character of the region. Most of the area is covered by Turkish red pine (Pinus brutia) forest and maquis. Cirali sand dunes are one of the few sites where 150 year old stone pine (Pinus pinea), found in Antalya region. Known as Chimeranean sage Phlomis chimerae (Peşmen, 1980) is a local endemic plant in Cirali (Tulek and Atik, 2017). Vegetation is one of the most important factors that determine the starting point and fire behavior of forest fires. Especially coniferous and dry character types such as Turkish pine create favorable conditions for fire, while broad-leaved and moist species such as Platanus orientalis, Laurus nobilis show a hard-burning and fire-preventing feature. Plant species in the Cirali region are classified according to their humidity characteristics (Figure 3).

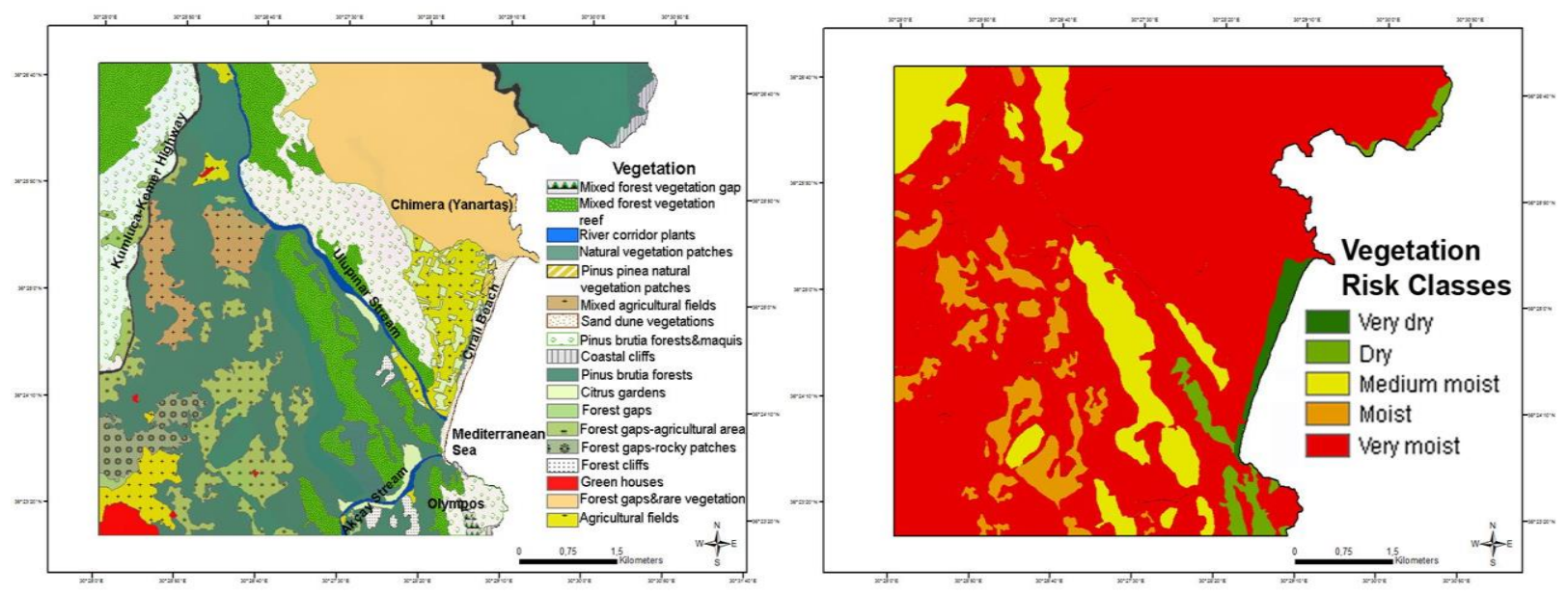

Figure 3. Vegetation and vegetation risk classes of Cirali region. 


\subsubsection{Topography}

The borders of the Cirali region remain within the Kumluca district. Kumluca district, which attracts attention with its mountains, plains, valleys and plateaus, displays a colourful landscape among other districts of Antalya (Kumluca Municipality, 2019). The topographic features that are effective in the formation and spread of forest fires are slope and aspect. In the areas where the slope values are high, the progression of the fire takes place faster, while in the areas where the slope values decrease, the rate of fire progression is slower (Özşahin, 2014). Since slope and aspect conditions affect sunbathing time and humidity conditions, they appear as the criteria to be considered in fire risk analysis (Karabulut et al., 2013). Slope and aspect classifications of Cirali can be seen in Figure 4.
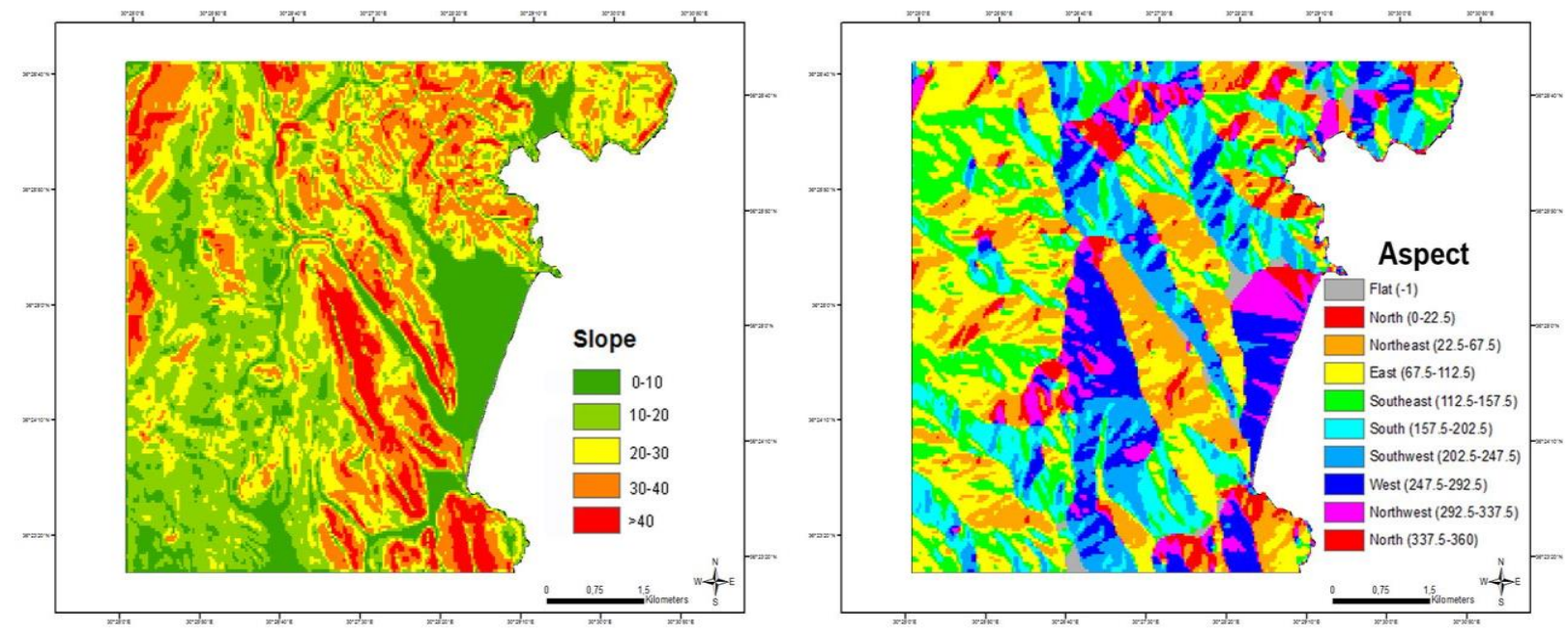

Figure 4. Slope and aspect classifications of Cirali region.

\subsubsection{Distance to the road and the residential}

Since the roads are constantly in motion, people and vehicles form a large ground for the formation of humaninduced fires (Karabulut et al., 2013). The sections of the forests close to the road have been defined as areas where fire sensitivity is high (Jaiswal et al., 2002; Erten et al., 2005; Joaquim et al., 2007; Karabulut et al., 2013; Özşahin, 2014).

Fire is more likely to occur in the parts of the forests close to the residential areas. Human activities pose a high risk of the occurrence of fires as a result of accident or neglect (Jaiswal et al., 2002; Erten et al., 2005; Joaquim et al., 2007). Although the level of risk decreases as we move away from the residential areas, the spread of human activities to large areas today causes the risk areas to spread to a wide area. The distance classification of the study area to the road routes and residentials can be seen in Figure 5.

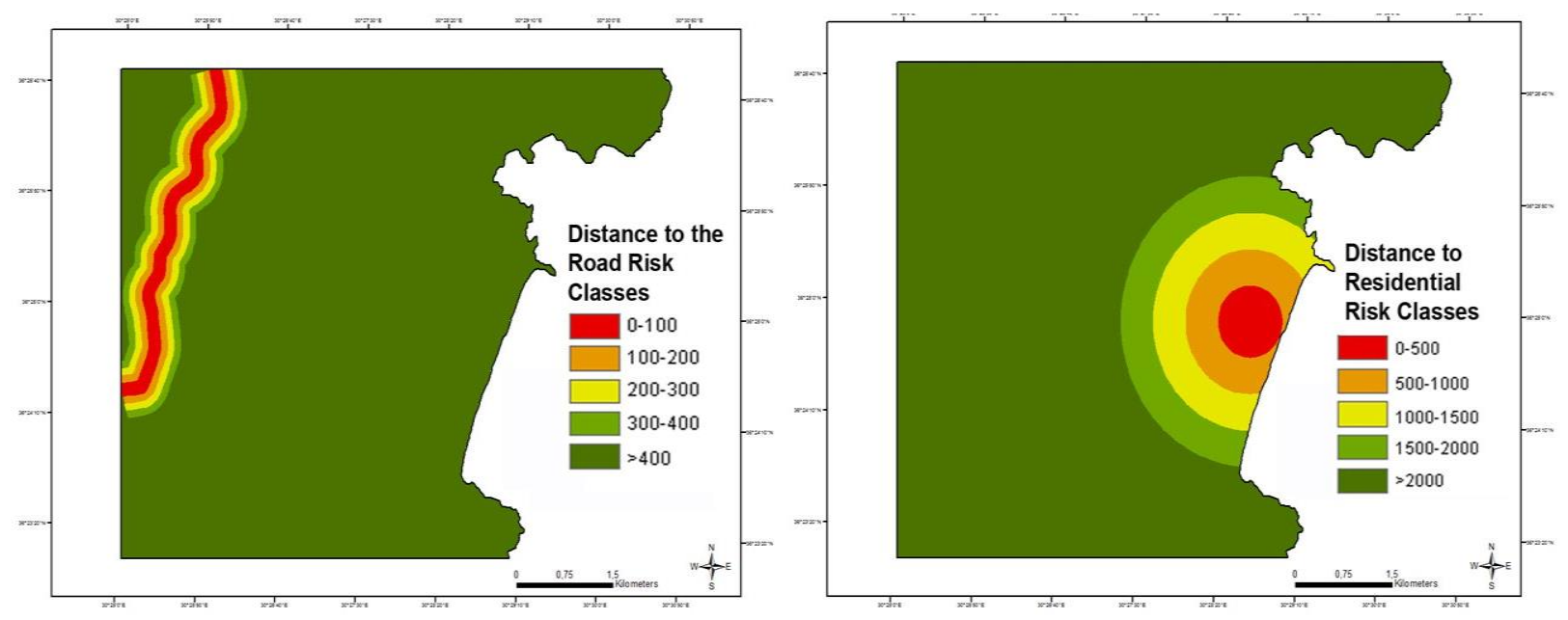

Figure 5. Distance to the road and residential classes. 


\subsubsection{Fire risk factors of Cirali}

When the vegetation of the research area is examined, it is observed that dry and very dry plant species such as Turkish pine (Pinus brutia), which pose a high risk, show a great spread with $46 \%$ of the area's Turkish pine forests. In this case, it can be said that most of the Cirali region vegetation consists of species with high burning potential. It is an important factor in the formation of fire in topography. Due to the geometrical structure of the study area, the aspect conditions have a balanced distribution. It is scattered on the south-west slopes with the greatest risk of fire. When the slope levels are examined, it is seen that the areas with a slope of $20^{\circ}$ and above have a distribution of $15 \%$ (Figure 6). There is Kumluca-Kemer Highway route within the study area. When examined within this scope, approximately $10 \%$ of the forest area of Cirali region is determined as the areas where the risk of fire related to the road is high and very high. Also residential areas, which are widely spread close to the coast of Cirali region, pose a high and very high risk in $6 \%$ of the area.
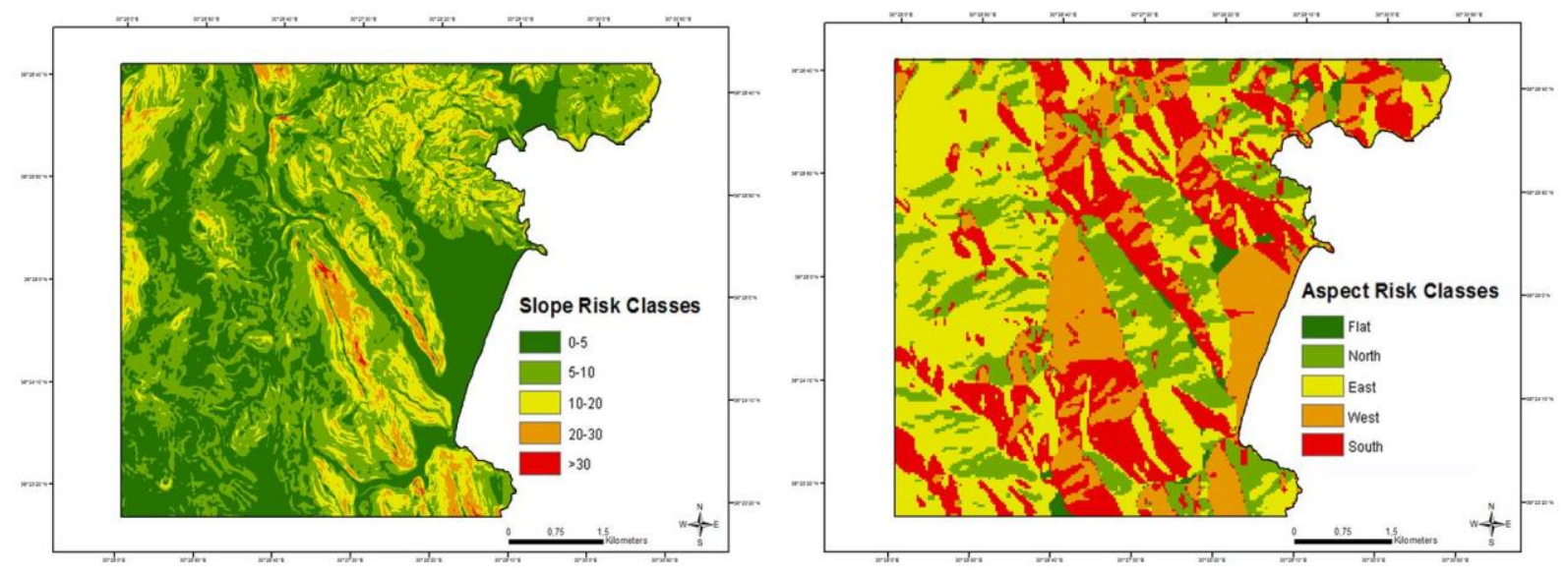

Figure 6. Slope and aspect risks classes.

According to the fire risk map, it can be seen that the high fire risk is spread over large areas. High risky areas are concentrated at altitudes where forest formation is concentrated. Fire risk increases where residential areas and roads approach each other (Figure 7).

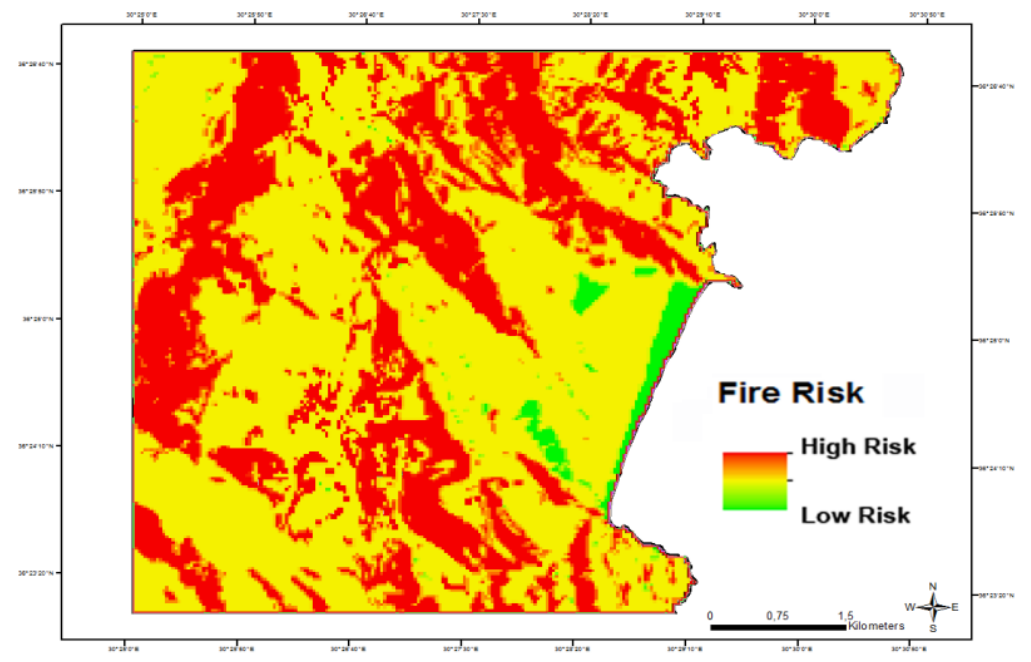

Figure 7. Fire risks classes.

\section{Results and Discussion}

There are very close relationships between a) tourism and environmental natural conditions, b) human-induced effects on the environment from tourism and other activities and c) unforeseen natural and anthropogenic hazards (Romagosa et al., 2014). Fires are among the unforeseen natural and anthropogenic hazards mentioned here. 
The protection of Cirali region is the most important obstacle preventing construction in the area. For this reason, natural texture is generally preserved. However, due to the geographical location and climatic data of Antalya province, one of the biggest threats related to the regional landscapes is fires that may occur due to natural or anthropogenic effects.

In this study, fire risk areas of the region were determined. In these areas, possible situations and results that a possible big fire may cause for tourism of region have been evaluated with DPSIR analysis. Accordingly, the DPSIR model regarding the effects of possible fires on the Çıralı region is given in Table 2.

Table 2. DPSIR analysis of the pressure, situation and responses of fires on Cirali region.

\begin{tabular}{|c|c|c|c|}
\hline $\begin{array}{l}\text { Driving forces } \\
\text { (D) }\end{array}$ & $\begin{array}{l}\text { Pressures } \\
\text { (P) }\end{array}$ & $\begin{array}{l}\text { State } \\
\text { (S) }\end{array}$ & Impact (I) / Response (R) \\
\hline Fires & $\begin{array}{l}\text { - Geographical and } \\
\text { climatic conditions } \\
\text { - Global warming } \\
\text { - Effects that may } \\
\text { arise from tourism } \\
\text { activities } \\
\text { - Direct or indirect } \\
\text { effects of local } \\
\text { people } \\
\text { - Unplanned and } \\
\text { illegal construction } \\
\text { - Human pressure }\end{array}$ & $\begin{array}{l}\text { - The } \\
\text { fragmentation of } \\
\text { landscapes } \\
\text { - Landscape } \\
\text { change }\end{array}$ & $\begin{array}{l}\text { - Damage to flora and fauna } \\
\text { - Environmental pollution } \\
\text { - Air pollution } \\
\text { - Image pollution } \\
\text { - Pollution of water resources } \\
\text { - Soil infertility } \\
\text { - The disappearance of natural landscape } \\
\text { - Change in topography } \\
\text { - Pollution of water resources } \\
\text { - Decreased agricultural production } \\
\text { - Decreased tourism activities and } \\
\text { demands }\end{array}$ \\
\hline
\end{tabular}

According to the results of DPSIR analysis showing the relationship between Cirali tourism and fires, fires mostly occur with geographical and climatic conditions, global warming, effects that may arise from tourism activities, direct or indirect effects of local people, unplanned and illegal construction and human pressure. This creates situations that can cause the landscape to be fragmented and change. The effects and reactions of such a driving force can be listed as damage of flora and fauna, environmental pollution, air pollution, image pollution, pollution of water resources, soil infertility, destruction of natural landscape, change in topography, pollution of water resources, decrease in agricultural production and decrease in tourism activities.

\subsection{Discussion}

Forest fires, which are among the important risks for the change of regions, are a very serious threat that can cause millions of hectares of forest areas to disappear every year worldwide, large amounts of money to fight fire and even loss of life and property. Loss of forest areas as a result of fires brings about disasters such as erosion, deterioration of water resources, air pollution, desertification, flood, landslide and avalanche (Koç, 2010; Y1ldırım, 2013). The 12 million hectares of our country, located on the $1700 \mathrm{~km}$ coastline, including the Mediterranean and Aegean coasts, constitutes the "sensitive" region in terms of forest fires (Başaran et al., 2004; Yıldırım, 2013). Cirali is also among the sensitive regions.

Analysis made in the research reveal the fire risk of Cirali. There are big and small fires in Cirali almost every year and some of these fires (for example 2007 and 2016 fires in spring and summer periods) negatively affect both the tourism of the region and the country. It also causes a decrease in quality of life and economic losses, especially ecosystem degradations. Otrachshenko and Nunes (2019), in their study of the example of Portugal, have revealed that the number of visitors that had previously burnt down has decreased over the years. In order to prevent this, determination of fire risk areas is very important in making use of the areas that will minimize the risk in planning studies and in controlling and extinguishing possible fires (Y1ldırım, 2013).

Tourism in Cirali region revives in spring and summer months and the tourists coming to the region stay in singlestorey bungalow houses with gardens instead of concrete structures, so they feel like they are at home. Citrus gardens in the region also make the region special and tourists can spend time in these gardens. However, forest fires that can occur in the region, especially in spring and summer periods, can threaten the region and facilities with the effect of the location and winds. For example, the fires that broke out in the region in June 2016 lasted for 2 days and local people and tourists were evacuated from the region. 
For many countries in the world, tourism is one of the most important sectors for economic development. However, the fact that the tourism sector is vulnerable to forest fires is an economically worrying situation (Otrachshenko and Nunes, 2019). For this reason, it is very important to create new tourism policies and strategies in order to guarantee a long-term tourism development. In addition to the economic dimension, the environmental dimension should be added to these policies.

\section{References}

1. Anonymus (2020). Environmental indicator definition and classification. Ministry of Urban and Environment. https://cevreselgostergeler.csb.gov.tr/gosterge-kavrami-i-85623 (24.02.2020).

2. Başaran, M.A., Sarıbaşak, H., Cengiz, Y. (2004). Determination of the Basic Principles of Fire Fighting Plan (Example of Manavgat). Ministry of Environment and Forestry Western Mediterranean Forestry Research Directorate, Antalya, 102 s.

3. Erten, E., Kurgun, V., Musaoğlu, N. (2005). Establishing a Forest Fire Information System Using Remote Sensing and Geographic Information Systems, TMMOB 10. Conference, Ankara.

4. Giulietti, S., Romagosa, F., Fons Esteve, J., Schröder, C. (2018). Tourism and the Environment: Towards a reporting mechanism in Europe. European Environment Agency, European Topic Centre on Urban, Land and Soil Systems, 114 p, Spain.

5. Jaiswal, K., Mukherjee, S., Mukherjee, K. D., Saxena, R. (2002). Forest Fire Risk Zone Mapping From Satellite Imagery and GIS, International Journal of Applied Earth Observation and Geoinformation, 4 pp.110.

6. Joaquim, G. S., Bahaaeddin, A., Josep, R. C. E. (2007). Remote Sensing Analysis to Detect Fire Risk Locations, GéoCongrès-2007, Québec, Canada.

7. Karabulut, M., Karakoç, A., Gürbüz, M., Kızılelma, Y. (2013). Deteriınation of Forest Fire Risk Areas Using Geographical Information Systems in Başkonuş Mountain (Kahramanmaraş), The Journal of International Social Research, Volume: 6, Issue: 24.

8. Kemer Municipality, (2019). Tourism in Kemer, http://www.antalya-kemer.bel.tr/kemerde-turizm (20.12.2019).

9. Koç, S.N. (2010). Evaluation of renovation projects in post-fire forest zones with respect to landscape architecture: $\quad$ Antalya $\quad$ Serik-Taşağil region case. Master Thesis, Ankara Üniversity, Graduate School of Natural and Applied Sciences Department of Landcape Architecture, $145 \mathrm{~s}$.

10. Kumluca Municipality, (2019). Geography, http://www.kumluca-bld.gov.tr/19/COGRAFYA.html (20.12.2019).

11. Otrachshenko, V., Nunes, L.C. (2019). Fire takes no vacation: Impact of fires on tourism. Working paper, NOVA, Portual, $25 \mathrm{p}$.

12. Özşahin, E. (2014). Forest Fire Sensitivity Analysis Using AHP and CBS: Antakya Forest Enterprise Directorate, Route Educational and Social Science Journal, Volume 1(3), October.

13. Peşmen, H. (1980). Flora of the Olympos-Beydaglari National Park. TÜBİTAK Basic Sciences Research Group, Project No.TBAG-335, Hacettepe University, Faculty of Science, Botany Department, Ankara.

14. Romagosa, F.R., Fons, J., Schröder, C., Giuletti, S., Stanik, R. (2014). Report on Feasibilty for Regular Assessment of Environmental Impacts and Sustainable Tourism in Europe. European Environment Agency, 102 p, Malaga, Spain.

15. Sharples, J., Mcrae, R., Weber, R., Gill A. (2009). A simple index for assessing fire danger rating. Environmental Modelling and Software, 24(6): 764-774.

16. Tulek, B., Atik M. (2017). Evaluation of Landscape Services with Landscape Metrics in Çıralı, Antalya, IOSR Journal of Environmental Science, Toxicology and Food Technology, Volume 11, Issue 10 pp. 16-25.

17. Yamaner, B. (2008). Ecotourism in the Scope of Sustainable Development: The Case of Çıralı. Master thesis. Ministry of Culture and Tourism, General Directorate of Investments and Enterprises, Ankara, $109 \mathrm{~s}$.

18. Yıldırım, E. (2013). Assessment of landscape change in the manavgat river basin in the contex of landscape protection, planning and management. PhD Thesis, Akdeniz Üniversity, Graduate School of Natural and Applied Sciences Department of Landcape Architecture, $151 \mathrm{~s}$. 